\title{
Complex Phototherapy for Compensation of Damages Induced by High-Intensing Laser Radiation in Experiment
}

\author{
DOI: $10.17691 /$ stm2015.7.4.10
}

Received August 22, 2015

A.P. Bavrina, PhD, Associate Professor, Department of Medical Physics and Informatics;

S.L. Malinovskaya, DSc, Professor, Department of Medical Physics and Informatics;

R.R. Alakaev, MD, PhD, Senior Lecturer, Department of Medical Physics and Informatics;

V.A. Monich, DSc, Professor, Head of the Department of Medical Physics and Informatics

Nizhny Novgorod State Medical Academy, 10/1 Minin and Pozharsky Square, Nizhny Novgorod, 603005, Russian Federation

The aim of the investigation was to develop a new technology of complex phototherapy based on consecutive biological tissue exposure to high-intensity laser radiation and low-intensity broadband red light and to evaluate its possibilities in experiment.

Materials and Methods. There were studied the effects of consecutive exposure of white rat tissues to high-intensity red and infrared radiation and low-intensity broadband red light on spontaneous and metal-catalyzed oxidative modification of proteins. The study was performed on white outbred rats with a body mass of 180 to $250 \mathrm{~g}$, which were divided into 5 groups. Control group 1 included animals whose inner surface of the thigh was exposed locally to laser light radiation with a wavelength of $671 \mathrm{~nm}$ (red laser) and the power of $50 \mathrm{~mW}$. Test group 2 underwent locally red laser radiation of the inner femoral surface and three consecutive sessions of low-intensity broadband red light exposure (a wavelength of $630 \mathrm{~nm}$, light spot intensity of $5 \mathrm{~mW} / \mathrm{cm}^{2}$ ). Control group 3 was exposed locally to $980 \mathrm{~nm}$ laser radiation of the inner femoral surface (infrared laser with the power of $50 \mathrm{~mW}$ ). Test group 4 was exposed locally to infrared laser radiation of the inner femoral surface and three consecutive sessions of low-intensity broadband red light. Group 5 (intact) was not exposed to radiation. Samples of femoral tissue and blood serum were taken on day 3 in all groups of animals.

Results. The content of neutral and basic aliphatic dinitrophenylhydrazons in the tissues exposed to red and infrared laser radiation was found to be increasing. In subsequent sessions of low-intensity red light phototherapy there occurred sharp decrease in the levels of protein oxidative modification products to normal values.

Conclusion. The developed technology of complex phototherapy including sessions of consecutive exposure of biological tissues to laser and broadband red light provides radiation safety of procedures.

Key words: red light; protein oxidative modification; high-intensity laser radiation.

Lasers generating intensities around a few watts and even dozens of watts per a square centimeter are widely used in medicine, for example, for photodynamic therapy of oncological patients. Such high-intensity light may cause serious side effects in human and animal organism, including burns, eye lesions, CNS disorders, cardio-vascular and endocrine abnormalities, genetic alterations [1]. When radiation doses are high it is possible to observe local rise of temperature, inhibition of tissue and organ functions, when they are super-high there may occur tissue ablation and a burn in the light spot area [2,3].

Numerous investigations [4-6] show that low-intensity red light can also influence the functional condition of live cells, tissues, organs, an organism as a whole and act as a factor fully or partially compensating oxidative stress consequences. Hence, it seems urgent to explore phototherapeutic techniques that allow to compensate fully or partially oxidative stress sequelae of organism tissue exposure to high-intensity light pulses and to provide radiation safety of photodynamic therapy and treatment of inappropriate light effects. The content of free-radical protein oxidation products in the light spot area of the irradiated object may serve an objective index of the organism alteration level by a physical agent and sequelae compensation processes.

The aim of the investigation was to develop a new technology of complex phototherapy based on consecutive exposure of biological tissues to highintensity laser radiation and low-intensity broadband red light and to estimate such possibilities in experiment.

Materials and Methods. The study was performed on white outbred rats with a body mass of 180 to $250 \mathrm{~g}$, which were divided into 5 groups. Control group 1 included 10 animals whose inner surface of the thigh was locally exposed to laser light radiation with a wavelength of $671 \mathrm{~nm}$ (red laser) and the power of $50 \mathrm{~mW}$. Laser radiation intensity in the light spot area was $0.55 \mathrm{~W} / \mathrm{cm}^{2}$ with $5 \mathrm{~min}$ exposure time for each field (the radiation area was divided into 9 fields each $1 \mathrm{~mm}^{2}$ in size).

Test group 2 included 10 rats which underwent laser radiation of the inner femoral surface locally according

For contacts: Bavrina Anna Petrovna, e-mail: annabavr@rambler.ru 
to the same scheme as the control group and three subsequent sessions of low-intensity broadband red light exposure afterwards (once a day for $20 \mathrm{~min}$ ). Laser radiation intensity in the light spot area was $5 \mathrm{~mW} / \mathrm{cm}^{2}$. The light of a super-bright LED with the maximum radiation spectrum of $630 \mathrm{~nm}$ and a half-height width of $20 \mathrm{~nm}$ was used in the experiment.

Control group 3 and test group 4 each included 10 animals whose inner femoral surfaces were locally exposed to high-intensity infrared (IR) laser radiation. The experiment, aimed to study the effects of IR laser radiation on free-radical protein oxidation, was carried out according to the schemes of groups 1 and 2, respectively. The intensity of laser radiation and the source of broadband light in the light spot area also amounted to $0.55 \mathrm{~W} / \mathrm{cm}^{2}$ and $5 \mathrm{~mW} / \mathrm{cm}^{2}$, respectively, IR radiation wavelength was $980 \mathrm{~nm}$.

Group 5 (intact) included 10 rats, which were not exposed to radiation.

The ethical principles established by the European Convention for the Protection of Vertebrate Animals used for Experimental and other Scientific Purposes (adopted in Strasburg on 18.03.1986 and confirmed in Strasburg on 15.06.2006) and approved by the Ethics Committee of Nizhny Novgorod State Medical Academy were strictly followed in the study.

Samples of the femoral tissue and blood serum were collected on day 3 in all groups of animals. Protein oxidative modification (POM) products, neutral and basic aldehyde- and cetone-dinitrophenylhydrazons, were determined by the level of carbonyl derivatives [7].
Spontaneous POM characterizes constitutive activity of POM; induced and metal-catalyzed POM characterizing $\mathrm{POM}$ increment after stimulation indicates the quantity of the substrate for POM and the possibility of its involvement in these processes [7]. According to the authors, metal-catalyzed POM technique makes it possible to determine intermediate oxidation products by stimulating them to generate end products, i.e. carbonyl derivatives. Neutral aliphatic aldehyde-dinitrophenylhydrazons were registered at a wavelength of 356 and $363 \mathrm{~nm}$, neutral aliphatic cetonedinitrophenylhydrazons at $370 \mathrm{~nm}$ and basic aliphatic aldehyde- and cetone-dinitrophenylhydrazons at 430 and $530 \mathrm{~nm}$.

The results were statistically processed using application software package Microsoft Excel and SPSS Statistics (Version 21). Index reliability in the groups was evaluated using Student's t-test. Experimental data compliance with normal distribution was tested with Kolmogorov-Smirnov's test. The data were presented as mean and standard error of mean $(\mathrm{M} \pm \mathrm{m})$.

Results and Discussion. Analysis of spontaneous POM product content in the muscle tissue of laboratory animals (Table 1) shows that high-intensity laser radiation exposure is followed by statistically significant increase in the content of oxidation products in the biomaterial (control groups) $(p \leqslant 0.01)$, while subsequent low-intensity broadband red light radiation (test groups) causes decrease in these products. Also it should be underlined that red light laser radiation provides considerable growth of final POM products in the muscle

Table 1

The content of spontaneous protein oxidative modification products in the biomaterial of rats (unit of optical density/g of protein)

\begin{tabular}{|c|c|c|c|c|c|}
\hline \multirow{2}{*}{$\begin{array}{c}\text { Laser } \\
\text { wavelength }\end{array}$} & \multirow{2}{*}{ Intact group } & \multicolumn{2}{|c|}{ Control groups (1 and 3 ) } & \multicolumn{2}{|c|}{ Test groups (2 and 4 ) } \\
\hline & & Red light & IR radiation & Red light & IR radiation \\
\hline \multicolumn{6}{|c|}{ In the muscular femoral tissue } \\
\hline $356 \mathrm{~nm}$ & $0.314 \pm 0.003$ & $1.037 \pm 0.054^{*+}$ & $0.795 \pm 0.025^{\star+}$ & $0.691 \pm 0.023^{* *}$ & $0.495 \pm 0.002^{* *}$ \\
\hline $363 \mathrm{~nm}$ & $0.324 \pm 0.004$ & $0.994 \pm 0.054^{\star+}$ & $0.731 \pm 0.019^{\star+}$ & $0.387 \pm 0.011^{* *}$ & $0.523 \pm 0.002^{* *}$ \\
\hline $370 \mathrm{~nm}$ & $0.204 \pm 0.004$ & $2.190 \pm 0.045^{\star+}$ & $0.877 \pm 0.027^{\star+}$ & $1.110 \pm 0.059^{* *}$ & $0.325 \pm 0.010^{* *}$ \\
\hline $430 \mathrm{~nm}$ & $0.076 \pm 0.002$ & $0.818 \pm 0.037^{*+}$ & $0.429 \pm 0.043^{\star+}$ & $0.480 \pm 0.011^{* *}$ & $0.180 \pm 0.010$ \\
\hline $530 \mathrm{~nm}$ & $0.009 \pm 7.4 \cdot 10^{-6}$ & $0.059 \pm 0.008^{\star+}$ & $0.049 \pm 0.001^{\star+}$ & $0.015 \pm 0.003^{\text {* * }}$ & $0.014 \pm 0.002^{* *}$ \\
\hline \multicolumn{6}{|c|}{ In the blood serum } \\
\hline $356 \mathrm{~nm}$ & $0.40 \pm 0.006$ & $1.096 \pm 0.085^{\star}$ & $0.939 \pm 0.001^{\star+}$ & $1.061 \pm 0.081^{\text {* * }}$ & $0.648 \pm 0.015^{\star *}$ \\
\hline $363 \mathrm{~nm}$ & $0.404 \pm 0.006$ & $0.976 \pm 0.087^{\star}$ & $0.921 \pm 0.001^{\star+}$ & $0.934 \pm 0.067^{\star *}$ & $0.660 \pm 0.016^{* *}$ \\
\hline $370 \mathrm{~nm}$ & $0.452 \pm 0.005$ & $0.808 \pm 0.081^{*}$ & $0.864 \pm 0.001^{\star+}$ & $0.780 \pm 0.055^{\star *}$ & $0.617 \pm 0.016^{* *}$ \\
\hline $430 \mathrm{~nm}$ & $0.198 \pm 0.001$ & $0.434 \pm 0.030^{*+}$ & $0.562 \pm 0.002^{\star+}$ & $0.395 \pm 0.015^{\star *}$ & $0.428 \pm 0.006^{* *}$ \\
\hline $530 \mathrm{~nm}$ & $0.008 \pm 0.001$ & $0.164 \pm 0.012^{*+}$ & $0.250 \pm 0.001^{\star+}$ & $0.051 \pm 0.009^{* *}$ & $0.048 \pm 0.001^{* *}$ \\
\hline
\end{tabular}

N o t e. Statistically significant differences $(p \leqslant 0.05)$ : * between intact and control groups; ${ }^{* *}$ between intact and test groups; ${ }^{+}$between control and test groups. 
tissue compared to the data obtained from the group exposed to IR (the exception being only neutral aliphatic aldehyde-dinitrophenylhydrazons registered at $363 \mathrm{~nm}$ ). Therewith, oxidation products of neutral character prevailed in the samples irradiated by red light, and basic POM products prevailed after IR radiation exposure. The reverse tendency was observed in the blood serum (high-intensity IR radiation led to a greater content of POM products than red laser light).

Subsequent exposure of the same femoral area of a rat to low-intensity red light caused considerable accumulation of final protein oxidation products in the muscle tissue homogenate. This effect was observed in both test groups which underwent prior exposure to high-intensity laser light (both red and IR spectrum) and subsequent low-intensity red light exposure. Despite the fact that the absolute value of POM product content in the test groups was significantly higher than the respective content in the intact group the ratio of POM content in the test and control groups exposed to high-intensity red light amounted to 2.32, and the ratio in the groups exposed to IR laser radiation was nearly 2.36. Thus, a session of exposure to low-intensity red light provided more than twofold decrease in the level of POM products.

Statistically significant decrease in the level of spontaneous POM products in the muscular femoral tissue and the blood serum of both test groups of animals suggests activation of the anti-oxidant system of the organism. In this case the effect of final POM product reduction was more significant in rats' muscular tissue than in their blood serum.
The performed study of induced POM process activity under exposure of laboratory animals' muscular femoral tissue to high-intensity laser light also demonstrated sharp increase in the level of POM products and equally significant decrease in intermediate POM products in the test groups exposed to consecutive low-intensity red light (Table 2).

Considering the effects of red and IR radiation on induced POM it should be noted that the studied products have reverse content dynamics in the blood serum compared to their levels in the muscular tissue. Thus, basic aldehyde- and cetone-dinitrophenylhydrazons prevail in the blood serum of rats exposed to highintensity red light while after IR laser exposure products of neutral character prevail. With subsequent exposure of the irradiated area to low-intensity red light the level of above-listed protein oxidation products decreases.

Similar effects of normalization of POM processes and antioxidant enzyme activation in phototherapy of organs and tissues exposed to ionizing radiation were also observed by us $[8,9]$. The reported effects of decreased POM product levels in the tissues of animals exposed to high-intensity laser radiation and subsequent lowintensity red light result from a cascade of photochemical reactions. They involve decomposition of molecular nitrosyl complexes (including cytochrome $\mathrm{C}$ oxidase); subsequent stimulation of mitochondrial respiratory chain in the cells of tissues irradiated by low-intensity red light [10]; vasolytic effect due to the release of free nitric oxide in the blood flow; ATP synthesis stimulation and energy deficit elimination in the damaged cells [11];

Table 2

The content of induced protein oxidative modification products in the biomaterial of rats (unit of optical density/g of protein)

\begin{tabular}{|c|c|c|c|c|c|}
\hline \multirow{2}{*}{$\begin{array}{c}\text { Laser } \\
\text { wavelength }\end{array}$} & \multirow{2}{*}{ Intact group } & \multicolumn{2}{|c|}{ Control groups (1 and 3 ) } & \multicolumn{2}{|c|}{ Test groups (2 and 4 ) } \\
\hline & & Red light & IR radiation & Red light & IR radiation \\
\hline \multicolumn{6}{|c|}{ In the muscular femoral tissue } \\
\hline $356 \mathrm{~nm}$ & $0.049 \pm 0.001$ & $0.184 \pm 0.007^{\star+}$ & $0.085 \pm 0.001^{\star+}$ & $0.072 \pm 0.001$ ** & $0.059 \pm 0.002^{* *}$ \\
\hline $363 \mathrm{~nm}$ & $0.048 \pm 0.001$ & $0.160 \pm 0.008^{\star+}$ & $0.085 \pm 0.001^{\star+}$ & $0.073 \pm 0.001$ & $0.062 \pm 0.001$ \\
\hline $370 \mathrm{~nm}$ & $0.029 \pm 0.001$ & $0.163 \pm 0.006^{\star+}$ & $0.074 \pm 0.001^{\star+}$ & $0.060 \pm 0.001$ & $0.060 \pm 0.007$ \\
\hline $430 \mathrm{~nm}$ & $0.017 \pm 0.001$ & $0.058 \pm 0.001^{*+}$ & $0.077 \pm 0.012^{\star+}$ & $0.045 \pm 0.001$ & $0.023 \pm 0.001$ \\
\hline $530 \mathrm{~nm}$ & $0.005 \pm 0.001$ & $0.050 \pm 0.001^{\star+}$ & $0.029 \pm 0.001^{\star+}$ & $0.031 \pm 0.001$ & $0.012 \pm 0.001^{* *}$ \\
\hline \multicolumn{6}{|c|}{ In the blood serum } \\
\hline $356 \mathrm{~nm}$ & $0.040 \pm 0.001$ & $0.125 \pm 0.001^{\star+}$ & $0.153 \pm 0.050$ & $0.072 \pm 0.001$ ** & $0.099 \pm 0.020$ \\
\hline $363 \mathrm{~nm}$ & $0.038 \pm 0.001$ & $0.106 \pm 0.002^{*}$ & $0.147 \pm 0.040^{\star+}$ & $0.087 \pm 0.001^{\star *}$ & $0.054 \pm 0.001^{* *}$ \\
\hline $370 \mathrm{~nm}$ & $0.044 \pm 0.001$ & $0.111 \pm 0.001^{\star+}$ & $0.139 \pm 0.043$ & $0.079 \pm 0.001^{* *}$ & $0.044 \pm 0.001$ \\
\hline $430 \mathrm{~nm}$ & $0.018 \pm 0.001$ & $0.053 \pm 0.001^{\star+}$ & $0.044 \pm 0.001^{\star+}$ & $0.041 \pm 0.001^{\star *}$ & $0.023 \pm 0.001^{* *}$ \\
\hline $530 \mathrm{~nm}$ & $0.002 \pm 0.001$ & $0.050 \pm 0.001^{* * *}$ & $0.110 \pm 0.047^{\star+}$ & $0.009 \pm 0.001$ & $0.032 \pm 0.001^{* *}$ \\
\hline
\end{tabular}

N o t e. Statistically significant differences $(p \leqslant 0.05)$ : * between intact and control groups; ${ }^{* *}$ between intact and test groups; ${ }^{+}$between control and test groups. 
photo-activation of antioxidant enzymes, such as superoxide dismutase, catalase, NO-synthase [12], glutathione peroxidase and myeloperoxidase [13]. All these reactions directly or indirectly modify chain processes of protein oxidation making it possible to consider POM product level to be a marker characterizing the efficacy of light radiation sessions. The obtained data enable us to offer a new method of complex phototherapy for the tissues damaged by high-intensity laser radiation.

Conclusion. The performed study allowed us to prove the application efficiency of methods of determining POM product content and evaluating the consequences of muscular tissue exposure to high-intensity laser radiation. The obtained data make it possible to offer new technology of complex phototherapy involving sessions of consecutive exposure of live tissues to laser and broadband red light, which provides radiation safety of procedures.

Study Funding and Conflicts of Interest. This study was not funded by any sources, and there is no conflicts of interest associated with this study.

\section{References}

1. Buravlev E.A., Zhidkova T.V., Vladimirov Y.A., Osipov A.N. Effects of laser and LED radiation on mitochondrial respiration in experimental endotoxic shock. Lasers Med Sci 2013; 28(3): 785-790, http://dx.doi.org/10.1007/s10103-0121155-7.

2. Kondratyev A.S., Mikhailova I.A., Petrishchev N.N. Modeling of different degrees of microvessel laser-induced endothelium damage. Rossiyskiy fiziologicheskiy zhurnal im. I.M. Sechenova 2013; 99(6): 745-750.

3. Petrischev N.N., Yantareva L.I., Fokin S.I. Dependence of infra-red laser emission (IrLE) photo-effect on the power flux density (PFD) and functional state of biological objects (infusoria Spirostomum ambiguum). Lazernaya meditsina 2005; 9(3): 43-48.

4. Bavrina A.P., Monich V.A., Malinovskaya S.L., Yakovleva E.I., Bugrova M.L., Lazukin V.F., Bavrina A.P.,
Monich V.A., Malinovskaya S.L., Yakovleva E.I., Bugrova M.L., Lazukin V.F. Correction method for radiation-induced heart disease consequences by low-intensity electromagnetic radiation in experiment. Bulleten' eksperimental'noj biologii $i$ mediciny 2015; 159(1): 115-119.

5. Karu T., Pyatibrat L. Gene expression under laser and light-emitting diodes radiation for modulation of cell adhesion: possible applications for biotechnology. IUBMB Life 2011; 63(9): 747-753, http://dx.doi.org/10.1002/iub.514.

6. Monich V.A., Drugova O.V., Lazukin V.F., Bavrina A.P. Low-power light and isolated rat hearts after ischemia of myocardium. J Photochem Photobiol B 2011; 105(1): 21-24, http://dx.doi.org/10.1016/j.jphotobiol.2011.06.006.

7. Dubinina E.I., Burmistrov S.O., Khodov D.A., Porotov I.G. Oxidative modification of human blood serum proteins, and the method of its determination. Voprosy meditsinskoy khimii 1995; 41(1): 24-26.

8. Bavrina A.P., Monich V.A., Malinovskaya S.L., Ermolaev V.S., Druzhinin E.A., Kuznetsov S.S. Correction of ionizing irradiation consequences with low-intensity light. Bulleten' eksperimental'noj biologii i mediciny 2013; 156(11): 608-610.

9. Malinovskaya S.L., Ermolayev V.S., Bavrina A.P., Monich V.A. Normalization of free-radical oxidation processes in muscular tissue in radiation disease by low-intensity red light exposure in experiment. Sovremennye tehnologii $v$ medicine 2014; 6(2): 32-37.

10. Mason M.G., Nicholls P., Wilson M.T., Cooper C.E. Nitric oxide inhibition of respiration involves both competitive (heme) and noncompetitive (copper) binding to cytochrome c oxidase. Proc Natl Acad Sci USA 2006; 103(3): 708-713, http://dx.doi. org/10.1073/pnas.0506562103.

11. laffaldano N., Meluzzi A., Manchisi A., Passarella S. Improvement of stored turkey semen quality as a result of $\mathrm{He}-$ Ne laser irradiation. Anim Reprod Sci 2005; 85(3-4): 317-325, http://dx.doi.org/10.1016/j.anireprosci.2004.04.043.

12. Moriyama Y., Nguyen J., Akens M., Moriyama E.H., Lilge L. In vivo effects of low level laser therapy on inducible nitric oxide synthase. Lasers Surg Med 2009; 41(3): 227-231, http://dx.doi.org/10.1002/lsm.20745.

13. Udut V.V., Prokop'ev V.A. Biophisical effects of $632.8 \mathrm{~nm}$ $\mathrm{HeNe}$ laser radiation on human blood and organism. Al'manakh klinicheskoy meditsiny 2006; 12: 41. 